\title{
ENDOMETRIAL STROMAL SARCOMA PADA SERVIKS UTERI
}

\author{
Poppy M. Lintong \\ Meilany F. Durry \\ Bagian Patologi Anatomi Fakultas Kedokteran Universitas Sam Ratulangi Manado \\ Email: poppylintong@gmail.com
}

\begin{abstract}
Endometrial stromal sarcoma (ESS) is a rare malignant tumor, about $0.2 \%$ of all malignant uterine tumors. Around $75 \%$ of ESS cases occur in females under 50 years, with clinical signs such as abdominal pain and bleeding per vaginam. The uterus usually enlarges, associated with polypoid tumors protruding into the uterine cavity which can be misdiagnosed with a leiomyoma. ESS occurs in the cervix, ovarium, or retroperitoneal areas, and can be derived from endometriosis in the pelvic cavity. The immunohistochemical test of the tumor cells is positive for CD10, which is typical to differ it from a leiomyoma. We reported a case of ESS in a woman of 43 years old, with a clinical diagnosis of myoma geburt. She complained of abdominal pain and a mass that came out of her vagina. Post operation, she was diagnosed as having a cervical myoma. The macroscopic examination showed enlargement of uterus tissues $15 \times 6 \times 7 \mathrm{~cm}$, thickened endometrium, and an exophytic tumor mass $(8 \mathrm{~cm})$ in the cervix, with cystic and necrotic parts in it. The microscopic examination showed endometrium hypertrophy in secretion phase, cervix with endometriosis, and ESS. ESS in uterine cervix is a rare case, and in this case it is related to endometriosis in the uterine cervix. Conclusion: This case was diagnosed as endometrial stromal sarcoma in the uterine cervix based on anamnesis, physical examination, histopathological examination, and immunohistochemistry positive for CD10.
\end{abstract}

Keywords: endometrial stromal sarcoma, endometriosis, uterine cervix

\begin{abstract}
Abstrak: Endometrial stromal sarcoma (ESS) merupakan tumor ganas yang jarang terjadi, hanya $0,2 \%$ dari semua tumor ganas di uterus. Sekitar $75 \%$ kasus terjadi pada wanita usia di bawah 50 tahun dengan gejala klinis nyeri perut dan perdarahan melalui jalan lahir. Uterus biasanya membesar disertai tumor polipoid menonjol dalam rongga uterus dan bisa disalah diagnosis sebagai leiomioma. ESS dapat terjadi juga di serviks uteri, ovarium, retroperitoneal, dan di rongga pelvis; dapat berasal dari endometriosis. Pemeriksaan imunohistokimia dari sel-sel tumor ESS yaitu positif untuk CD10, merupakan petanda tipikal untuk membedakannya dari leiomioma. Kami melaporkan kasus ESS pada seorang wanita berusia 43 tahun dengan keluhan nyeri perut dan adanya massa jaringan yang keluar dari jalan lahir. Diagnosis klinis ialah mioma geburt dan pasca operasi diduga sebagai mioma servikal. Pemeriksaan makroskopik menunjukkan jaringan uterus membesar berukuran $15 \times 6 \times 7 \mathrm{~cm}$, dan pada serviks terdapat massa tumor berukuran $8 \mathrm{~cm}$ eksofitik, dengan fokus kistik dan nekrotik. Hasil pemeriksaan mikroskopik menunjukkan serviks dengan endometriosis dan ESS. Pemeriksaan imunohistokimia positif untuk CD10. ESS pada serviks uteri merupakan kasus jarang yang berkembang dari endometriosis serviks uteri. Simpulan: Pada kasus ini diagnosis ESS pada serviks uterus ditegakkan berdasarkan anamnesis, pemeriksaan klinis, pemeriksaan histopatlogik, dan imunohistokimia CD10 positif.
\end{abstract}

Kata kunci: endometrial stromal sarcoma, endometriosis, serviks uteri

Endometrial stromal sarcoma (ESS) tergolong tumor stroma endometrium yakni suatu neoplasma berasal dari sel-sel stroma yang menyerupai fase proliferasi 
endometrium. ${ }^{1,2}$ Tumor stroma endometrium (Endometrial stromal tumor, EST) sangat jarang terjadi, ${ }^{2,3}$ mempunyai gejala klinik tidak spesifik berupa perdarahan vaginal dan pembesaran uterus. ${ }^{4}$ Umumnya ditemukan pada wanita usia reproduktif atau postmenopause rata-rata pada usia 53 tahun. ${ }^{4}$ Laporan lain menyebutkan usia rata-rata 47 tahun $^{2,5}$ dan sepertiga kasus terjadi pada wanita postmenopause, ${ }^{2}$ juga pada wanita usia pertengahan (rata-rata 45 tahun). ${ }^{6}$

EST pada uterus termasuk tumor mesenkimal kedua terbanyak dari uterus, dengan insiden $<10 \%$ dari semua tumor. ${ }^{7}$ Berdasarkan ketetapan WHO tahun 2003 klasifikasi EST saat ini terdiri atas 3 bagian yaitu: Endometrial stromal nodule (ESN), low-grade endometrial stromal sarcoma (ESS), dan undifferentiated endometrial/uterine sarcoma (UES). ${ }^{1,2,7}$

Endometrial stromal nodule (ESN) merupakan EST yang berdiferensiasi baik. Tumor berbatas jelas, biasanya soliter menonjol ke dalam kavum uteri, berwarna kekuningan. Tumor bersifat ekspansif dan tidak berinfiltrasi ke miometrium. Mikroskopik sel-sel tumor mirip stroma endometrium fase proliferasi, berbentuk bulat sampai oval, sitoplasma sedikit, uniform, dan kurang bermitosis. ${ }^{1}$ Salah satu gambaran yang karakteristik yaitu sel-sel tumor mengitari pembuluh darah arteriol spiralis secara konsentris., ${ }^{2,6}$ Gambaran mikroskopik lainnya dapat berupa jaringan ikat fibrosa, kolagen, miksoid hialinisasi, dan histiosit berbusa. ${ }^{2}$

\section{Low-grade endometrial stromal} sarcoma (ESS) mempunyai gambaran makroskopik tumor yang berbeda-beda. Uterus membesar dengan tumor polipoid menonjol dan distensi ke kavum uteri. Fokus nekrotik dan kistik dapat terjadi. Pada sebagian kasus ditemukan tumor berinfiltrasi ke dalam miometrium. Mikroskopik sel-sel tumor mirip dengan ESN yakni menyerupai sel-sel stroma endometrium fase proliferasi dengan sedikit sitoplasma. ${ }^{1}$ Gambaran lain ialah adanya sel-sel desidualisasi dengan sitoplasma eosinofilik dan inti bulat, beberapa dengan inti atipik, juga dapat ditemukan sel-sel busa. Aktifitas mitosis bisa $<3 / 10 \mathrm{HPF}$ atau lebih tinggi. ${ }^{2}$ Mitosis bisa <10/10HPFs, namun mitosis bukan merupakan kriteria diagnostik. ${ }^{1}$ ESS disebut juga endolymphatic stromal myosis karena dapat berinfiltrasi ke miometrium dan cenderung menembus pembuluh limf. ${ }^{1,2,6}$

Undifferentiated endometrial/uterine sarcoma (UES), merupakan EST gradasi tinggi. Dibandingkan dengan ESN dan ESS, mikroskopik sel-sel tumor lebih besar, inti lebih vesikuler dengan nukleoli mencolok dan kromatin inti bergumpal. Terdapat lebih banyak sel-sel dengan mitosis kira-kira 20/10HPFs atau lebih. Sel-sel tumor berinfiltrasi langsung ke miometrium dan bersifat destruktif. ${ }^{1}$ Juga terdapat lebih banyak sel-sel atipikal dan pleomorfik, sedangkan pola pembuluh darah tidak karakteristik. Umumnya UES sangat agresif dan berhubungan erat dengan komponen sarkoma dari malignant mixed Mullerian tumor (MMMT). ${ }^{6}$

Patogenesis EST berhubungan dengan translokasi kromosom $t(7: 17)$ dimana terjadi penyatuan/fusi dari 2 gen 'zinc finger' (JAZFI dan JJAZI). ${ }^{1,2,8}$

EST mempunyai reaksi difus terhadap CD10 meskipun varian fibrous tidak ada. ${ }^{1}$ Pemeriksaan CD10 umumnya positif untuk EST, namun juga positif untuk tumor otot polos, MMMT, dan rabdomiosarkoma. Hasil pewarnaan desmin bervariasi dan tidak dapat digunakan untuk membedakan EST dari tumor otot polos. Petanda tumor otot polos mencakup h-caldesmon, myosin, dan HDCA8 juga membantu untuk diagnosis banding., ${ }^{2,7}$ Bagian tumor dari diferensiasi otot polos positif untuk semua petanda otot plos seperti CD10. Bagian tumor dengan diferensiasi sex-cord dapat positif untuk inhibin, calretinin, CD-99, WT-1, dan Melan-A. EST juga sering positip untuk ER dan PR walaupun tidak spesifik. Pada studi 34 kasus EST, CD10 dapat juga digunakan untuk membedakannya dari tumor otot polos uterus. ${ }^{9}$

Ukuran tumor, penyebaran tumor keluar dari uterus, dan jumlah mitosis penting sebagai faktor prognostik tumor. 
Tumor berukuran $<4 \mathrm{~cm}$ tidak pernah rekuren. Demikian juga tumor yang hanya terbatas pada uterus saat operasi sangat jarang rekuren. ${ }^{6}$ Prognosis baik pada ESN bila dilakukan histerektomi. ${ }^{2}$ Pada ESS, tumor berpotensi ganas rendah tetapi dapat terjadi rekurensi dengan predileksi pada panggul, perut, dan vagina; jarrang terjadi pada paru-paru. ${ }^{2}$

\section{LAPORAN KASUS}

Seorang wanita usia 43 tahun masuk rumah sakit dengan keluhan nyeri perut bagian bawah disertai massa jaringan keluar dari jalan lahir dan sedikit perdarahan; diagnosis klinis ialah mioma geburt. Diagnosis penyakit sebagai mioma uteri sudah diketahui sejak beberapa bulan sebelum masuk rumah sakit dan telah dianjurkan untuk dioperasi. Saat dilakukan histerektomi terlihat uterus membesar, dan tampak massa tumor pada serviks sehingga diagnosis pasca operasi ditegakkan sebagai mioma servikal.

Pemeriksaan makroskopik menunjukkan uterus berukuran $15 \times 6 \times 7 \mathrm{~cm}$. Pada potongan melintang korpus uteri berukuran $7 \mathrm{~cm}$, endometrium sangat menebal. Pada serviks terdapat tumor berdiameter $8 \mathrm{~cm}$, batas jelas, konsistensi lunak, dan warna kuning kecoklatan dengan bagian yang kistik dan nekrosis (Gambar 1). Dinding vagina menebal.

Hasil pemeriksaan mikroskopik menunjukkan serat-serat otot miometrium hipertrofi, kelenjar endometrium berdilatasi dan berkelok-kelok, dan sel-sel kelenjar dalam fase sekresi. Serviks dengan kelenjar endoserviks membentuk kista retensi, pada beberapa tempat terlihat kelenjar endometrium di antara stroma (endometriosis) (Gambar 2). Bagian tumor terdiri dari selsel berbentuk bulat dan bulat lonjong dengan inti hiperkromatik, sel-sel tersebar monoton diantara matriks jaringan ikat miksomatik (Gambar 3), dan sebagian selsel mengitari pembuluh darah (Gambar 4). Disamping itu terlihat juga sel-sel desidualisasi dengan sitoplasma eosinofilik. Juga banyak sel-sel dengan mitosis
$>$ 10/4HPFs (Gambar 5). Sebagian inti sel menunjukkan atipia dan bizar, dan sebagian sel-sel dengan sitoplasma bervakuola (foam cells) (Gambar 6). Dari hasil pemeriksaan histopatologik disimpulkan sebagai endometrial stromal sarcoma pada serviks uteri. (perkembangan dari endometriosis serviks). Hasil pemeriksaan imunohistokimia ialah CD10 setempat positif sedang kuat pada sel stroma yang seluler terutama disekitar komponen 'glandular' (Gambar 7) sehingga disimpulkan bahwa massa tumor mengandung komponen ESS, kemungkinan merupakan komponen sarkoma dari suatu MMMT (Malignant mixed Mullerian tumor).

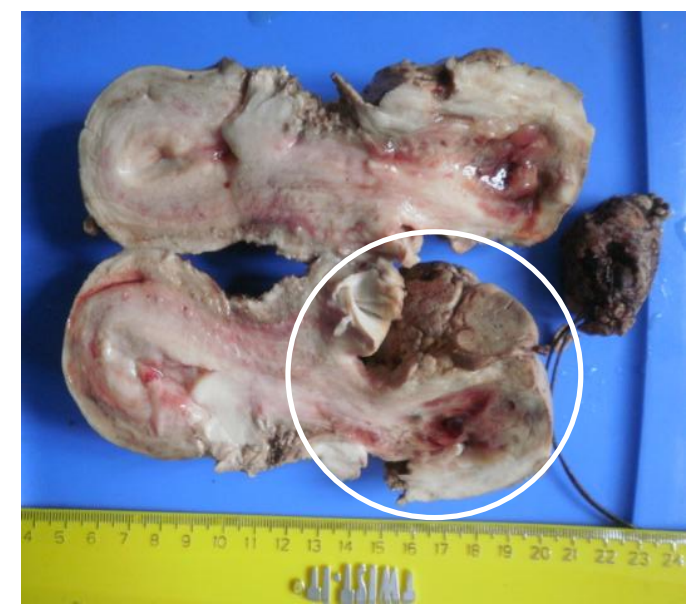

Gambar 1. Gambaran makroskopik ESS pada serviks uteri, tumor berukuran diameter $8 \mathrm{~cm}$, konsistensi lunak, warna coklat kekuningan dengan bagian kistik dan nekrotik

\section{BAHASAN}

ESS pada serviks uteri sangat jarang terjadi. ESS biasanya terjadi pada endometrium, sel sel tumor merupakan sisa stroma endometrium fase proliferasi dan menunjukkan spektrum dari perangai jinak (ESN) dan ganas (ESS). ${ }^{1,2}$ Diagnosis kasus ini ialah low grade ESS pada wanita 43 tahun dengan keluhan nyeri perut dan perdarahan dari jalan lahir. Dari semua tumor uterus yang ganas insiden ESS 0,2\%, sering terjadi pada usia pertengahan,40 dan 55 tahun, biasanya disertai perdarahan uterus abnormal dan nyeri perut. ${ }^{1,2}$ 


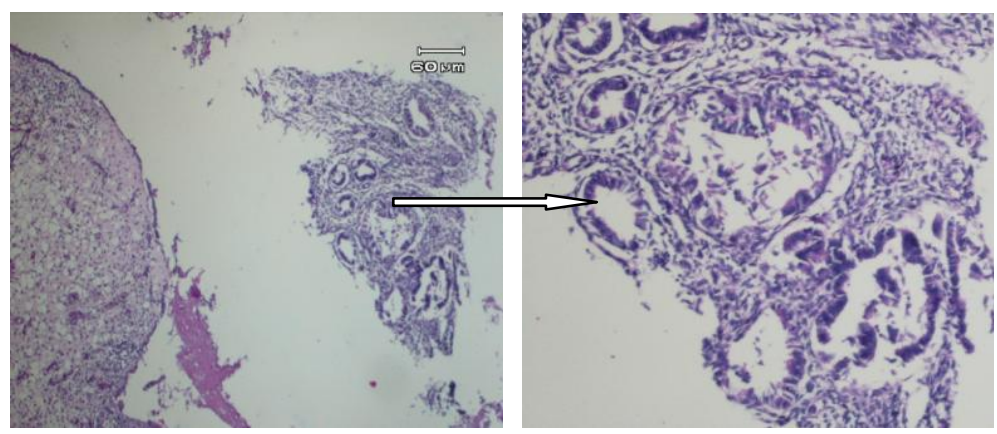

Gambar 2. Fokus jaringan endometrium terdiri dari stroma dan kelenjar berada di antara jaringan cerviks uteri (endometriosis)
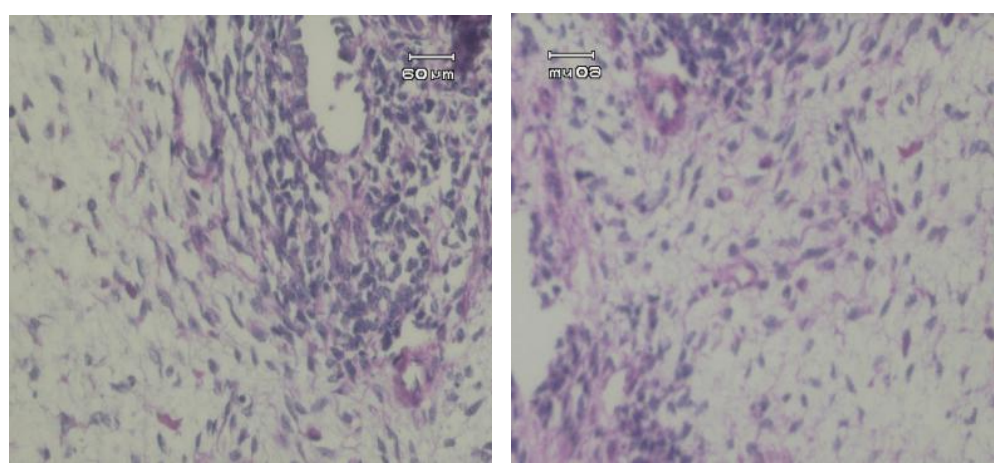

Gambar 3. Bagian tumor ESS pada serviks terdiri dari sel-sel berbentuk bulat dan bulat lonjong dengan inti hiperkromatik. Sel-sel tersebar monoton diantara matriks jaringan ikat miksomatik dan mengitari kelenjar endometrium
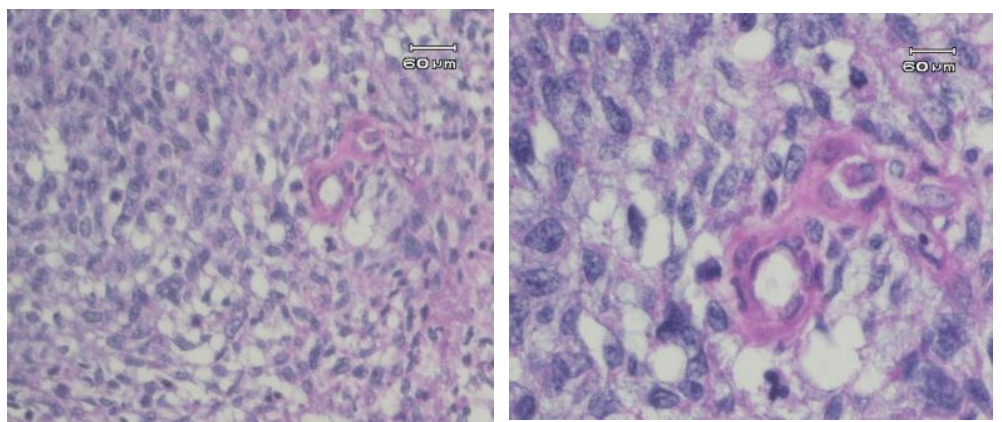

Gambar 4. Sel-sel tumor ESS mengitari pembuluh darah arteriol, beberapa pembuluh darah menebal dan hialinisasi, dan terlihat banyak mitosis
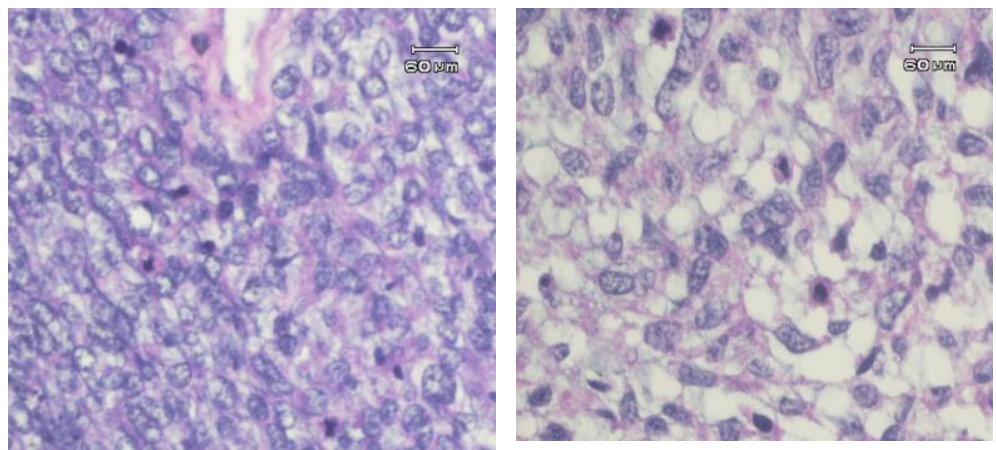

Gambar 5. Sel-sel tumor ESS tersusun padat berbentuk oval dan spindel, sebagian sel tampak desidualisasi dengan sitoplasma eosinofilik, sel-sel busa, dan mitosis tinggi >10/4HPFs 


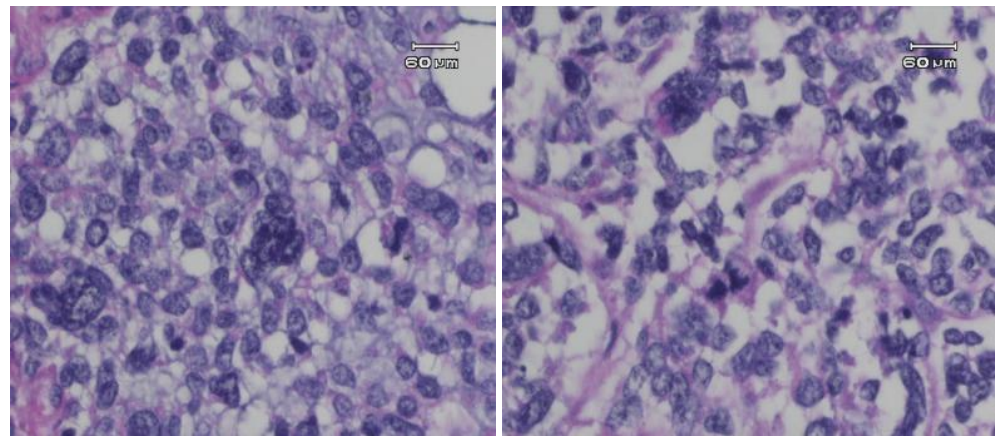

Gambar 6. Sel-sel tumor ESS tersusun padat dan monoton dan sebagian inti menunjukkan atipia dan bizar. Juga terlihat sel-sel busa (foam cells) dengan sitoplasma bervakuola

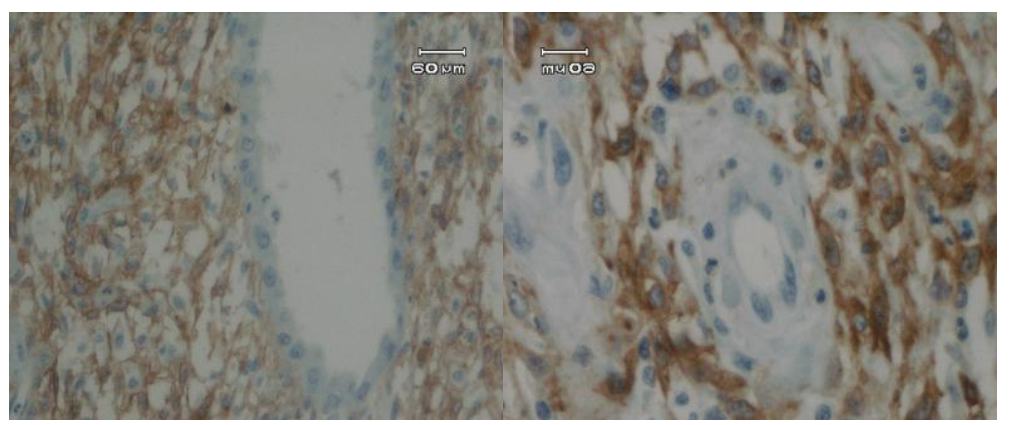

Gambar 7. Sel-sel tumor ESS dengan pengecatan imunohistokimia CD10 positif (warna coklat) sedang-kuat pada sel stroma yang seluler terutama sekitar kelenjar (kiri) dan sekitar pembuluh darah arteriol yang menebal (kanan)

Beberapa kasus EST dilaporkan berhubungan dengan penyakit polikistik ovarium, penggunaaan estrogen dalam waktu lama, atau pengobatan dengan tamoxifen; ${ }^{1,2}$ hal-hal tersebut tidak ditemukan pada kasus ini.

Umumnya ESS berada pada miometrium tetapi beberapa dapat timbul pada endometrium membentuk massa polipoid. ${ }^{1-3}$ Pada kasus ini massa tumor berukuran $8 \mathrm{~cm}$ berada pada serviks uteri, berbatas jelas dengan fokus nekrotik dan kistik (Gambar1). Kasus ESS pada serviks telah dilaporkan, salah satu berupa massa polipoid menonjol dalam orifisium serviks, ${ }^{10}$ dan satu kasus terjadi pada wanita usia 43 tahun, massa tumor pada serviks posterior yang tampak seperti mioma. ${ }^{11}$ Dari 2 kasus yang dilaporkan, temuan massa tumor pada serviks semula diduga sebagai mioma, seperti halnya pada kasus ini yang semula diduga sebagai mioma geburt dan pasca operasi diduga sebagai mioma servikal. Beberapa ESS yang timbul di luar uterus berasal dari endometriosis. ${ }^{5}$ Pada kasus ini ditemukan endometriosis pada serviks (Gambar 2) yang memperkuat diagnosis ESS.

Pemeriksaan imunohistokimia pada kasus ini memberi hasil CD10 positif. Hal ini sesuai dengan acuan pustaka yang menyebutkan bahwa hampir semua ESS positip untuk CD10, ${ }^{1,3,5}$ Pemeriksaan dengan desmin dan h-caldesom negatif pada ESS yang dapat membantu membedakannya dari leiomioma hiperseluler. ${ }^{1-4}$ Hasil penelitian Kurihara et al. ${ }^{12}$ pada 31 kasus menyimpulkan bahwa ESS sejati biasanya desmin negatif, ekspresi CD10 sering terlihat pada tumor otot polos termasuk leiomiosarkoma, dan hampir setengah dari leiomioma hiperseluler. Panel CD10, h-caldesmon, dan desmin dapat digunakan untuk membedakan EST dari leiomioma hiperseluler. Demikian juga penelitian Chu et al. ${ }^{9}$ pada 34 kasus yang 
menyimpulkan bahwa kombinasi pemeriksaan imuno-histokimia SMA, MSA, desmin, dan CD10 merupakan petanda imunohistokimia yang sangat berguna untuk diagnosis banding EST dengan leimiosarkoma dan leiomioma hiperseluler.

Gambaran mikroskopik kasus ini menunjukkan tumor hiperseluler, sel-sel bentuk bulat dan oval dengan inti hiperkromatik (Gambar 3). Ciri khas sel-sel ialah mengitari pembuluh darah dan kelenjar (Gambar 4); sel-sel dengn mitosis $>$ 10/4HPFs (Gambar 5); sel-sel dengan sitoplasma bervakuol dan beberapa sel dengan inti bizar (Gambar 6); serta pemeriksaan imunohistokimia CD10 positif sedang-kuat pada sel-sel stroma terutama disekitar pembuluh darah dan kelenjar (Gambar 7). Diagnosis ditegakkan sebagai ESS sesuai acuan pustaka. ${ }^{1-3}$ Pada analisis kasus untuk semua stadium, sel mitosis $\geq$ 10/10HPFs mempunyai harapan hidup kurang menguntungkan. Semakin banyak atipia sel, semakin besar angka relaps tumor. $^{13}$

Pada kasus ini ditemukan banyak mitosis, juga atipia sel dengan inti bizar sehingga kemungkinan tumor dapat rekuren dan cenderung menjadi UES. ESS mempunyai prognosis lebih baik daripada UES dengan angka harapan hidup 5 tahun pada stadium 1 sekitar $98 \%$, dan 10 tahun pada stadium 1 sekitar 89\%; dan sekitar $20 \%$ tumor stadium 1 dapat rekuren. ${ }^{1}$ Hasil studi Ashraf-Ganjoei et al. ${ }^{14}$ pada 14 kasus ESS mendapatkan 5 tahun angka harapan hidup $93 \%$.

\section{SIMPULAN}

Telah dilaporkan kasus ESS serviks pada seorang wanita berusia 43 tahun dengan keluhan nyeri perut dan perdarahan dari jalan lahir. Pada pemeriksaan klinis uterus membesar dan didiagnosis sebagai leiomioma. Diagnosis berdasarkan pemeriksaan histopatologik makroskopik dan mikroskopik menunjukkan ESS pada serviks, ditunjang oleh pemeriksaan imunohistokimia CD10 positif dan adanya temuan endometriosis servikal.

\section{DAFTAR PUSTAKA}

1. Mc Cluggage WG, Robboy SJ. Mesenchymal uterine tumors, other than pure smooth muscle neoplasm, and adenomyosis. In: Robboy's Pathology of the Female Reproductive Tract (2nd ed.). Robboy SJ, Mutter GL, Prat J, Bentley RC, Russel P, Anderson MC. 2009. Nama kota: Philadelphia: Churchill Livingstone Elsevier; p. 427-36.

2. Oliva E. Pure mesenchymal and mixed Mửllerian tumors of the uterus. In: Goldblum JR, editor. Gynecologic Pathology (1st ed.). Philadelphia Churchill Livingstone Elsevier, 2009; p. 293-302.

3. Silverberg SG, Tabbara SO. The uterine corpus. In: Silverberg SG, Silverberg's Principles and Practice of Surgical Pathology and Cytopathology Vol 2 (4th ed.). Philadelphia: Churchill Livingstone Elsevier, 2006; p. 1973-9.

4. Philip CB, Young RH. Atlas of Gynecologic Surgical Pathology (2nd ed.). Philadelphia: Saunders Elsevier, 2008; p. 212-9.

5. Norris HJ, Zaloudk CJ. Mesenchymal tumors of the uterus. In: Blaustein A, editor. Pathology of the Female genital Tract (2nd ed.). New York: SpringerVerlag, 1982; p. 376-84.

6. Rosai J. Rosai and Ackerman's Surgical Pathology Volume 2 (10th ed.). Edinburg: Mosby Elsevier, 2004; p.1501-4.

7. Oliva E. Endometrial stromal tumors. Boston: International Society of Gynecologic Pathologists USCAP Companion Meeting, 2009.

8. Hedrick EL, Pirog EC. The female genital tract. In: Kumar V, Abbas AK, Fausto $\mathrm{N}$, Aster JC. Robbins and Cotran Pathologic Basis of Disease (8th ed.). Philadelphia: Saunders Elsevier, 2010; p. 1036-7.

9. Chu PG, Arber DA, Weiss L, Chang LK. Utility of CD10 in distinguishing between endometrial stromal sarcoma and uterine smooth muscle tumors: An immunohistochemical comparison of 34 cases. Mod. Pathol. 2001:14(5):465-71.

10. Goh SL, Chuah KL, Chew SH, Tan PH. Uterine epiteloid endometrial stromal sarcoma presenting as a "cervical 
polyp". Ann. Diagn. Pathol. 2005;9(2): 101-5.

11. Hasiakos D, Papakonstantinou K, KondiPaphiti A, Fotious S. Low-grade endometrial stromal sarcoma of the endocervix report of a case and review of the literature. Eur J Gynecol Oncol. 2007;28(6):483-6.

12. Kurihara S, Oda Y, Iwasa A, Takahira T, Kaneki E, Kobayashi $\mathrm{H}$, et al. Endometrial stromal sarcomas and related high-grade sarcomas: immunohistochemical and molecular genetic study of 31 cases. Am J Surg
Pathol. 2008;32(8):1228-38. Doi: 10.1097/PAS.0b013e31816a3b42.

13. Chang KL, Crabtree GS, Lim-Tan SK, Kempson RL, Hendrickson MR. Primary uterine endometrial stromal neoplasms. Am J Surg Pathol. 1990;14:415-38.

14. Ashraf-Ganjoei T, Behtash Nadereh, Shariat Mamak, Asamosadat M. Low grade endometrial stromal sarcoma of uterine corpus, a clinico-pathological and survey study in 14 cases. World Journal of Surgical Oncology 2006;4:50. Doi:10.1186/1477-7819-4-50. 